\title{
Proceeding
}

8th INSHS International Christmas Sport Scientific Conference, 5-7 December 2013. International Network of Sport and

Health Science. Szombathely, Hungary

\section{The effect of smoking on visceral fat accumulation in Czech men and women}

\author{
ZUZANA HLAVOŇOVÁ $\square$, MARTIN SEBERA, EVA PAJEROVÁ \\ Masaryk University Faculty of Sports Studies Brno
}

\begin{abstract}
Hlavoňová, Z., Sebera, M. \& Pajerová, E. (2014). The effect of smoking on visceral fat accumulation in Czech men and women. J. Hum. Sport Exerc., 9(Proc1), pp.S552-S560. Many studies indicate that smoking is one of risk factors influencing the accumulation of visceral fat (VFA). The mechanism by which smoking contributes to the accumulation of visceral fat is not yet fully understood, but it is assumed that smoking increases the level of plasma cortisol, causes imbalance between male and female sex hormones in women, and decreases testosterone levels in men (Chiolero et al., 2008). The objection of this study was to evaluate the effect of smoking on the accumulation of VFA in the population of the Czech Republic. The research included 1,412 individuals of both genders divided into categories of smokers vs nonsmokers and physically active vs. physically inactive. VFA was measured by the device InBody 720 and information about physical activity and smoking was collected via a questionnaire. We supposed that smokers would have a higher percentage of VFA than non-smokers. The results showed that smokers had a higher amount of VFA, but the difference was not statistically significant. In contrast, statistically significant differences were found in the waist-to-hip ratio (WHR) and total \% body fat. Physically active individuals had a much more favourable results than physically inactive individuals. Remarkably, the amount of VFA, WHR and \% body fat tended to be smaller in smoking men than in non-smoking men, but higher in smoking women than in non-smoking women. Key words: SMOKING, VFA, WHR, PHYSICAL ACTIVITY,
\end{abstract}

\footnotetext{
Corresponding author. Masaryk University Faculty of Sports Studies Brno.

E-mail: zuzana.hlavonova@seznam.cz

8th INSHS International Christmas Sport Scientific Conference, 5-7 December 2013. International Network of Sport and Health Science. Szombathely, Hungary.

JOURNAL OF HUMAN SPORT \& EXERCISE ISSN 1988-5202

(C) Faculty of Education. University of Alicante

doi:10.14198/jhse.2014.9.Proc1.46
}

VOLUME 9 | Proc1 | 2014 | S552 


\section{INTRODUCTION}

Smoking and obesity are the most serious contemporary health risks that are connected with many types of cancer and cause insulin resistance leading to atherosclerosis and cardiovascular mortality. In general, they are the main causes of global morbidity and mortality. The combination of obesity and smoking increases the risk of premature death by more than ten times. Furthermore, we can add a huge negative impact on the psyche causing feelings of inferiority, depression, anxiety, worsening of the quality of life. Costs expended on the treatment of diseases caused by obesity and smoking are really high (Matoulek et al. 2010).

In the Czech republic, the prevalence of obesity has been rising during the recent years. A research conducted on a representative sample of the Czech population between 2008-2009 showed that 23\% Czech adults are obese and $34 \%$ suffer from overweight. Furthermore, it also showed a significant shift in the values of waist circumference in Czech men and women (Sucharda, 2010).

Although a certain amount of body fat is important, protects organs, envelops joints, stores vitamins and constitutes a reservoire of energy, excessive amount of fat in the body is dangerous to health. It was demonstrated that the risk of obesity increases with the number of smoked cigarettes and smoking is one of factors that influence the amount of abdominal fat in the body. Abdominal (belly) fat may be either subcutaneous (located between the skin and the abdominal wall) or visceral (in the abdominal cavity and around internal organs). Considering that visceral fat (VFA) is stored among organs, it can't be seen. However, if its amount increases above a certain threshold, it increases the volume of the abdomen and waist. Excessive amounts of this body fat belong to risk factors of certain cardiovascular and metabolic diseases, such as cardiac arrhythmia, hypertension, atherosclerosis, or insulin resistance (www.inbody.cz).

Smoking causes an increase in VFA, but the mechanism of this increase is not yet fully understood. One possible explanation lies in the imbalance between male and female sex hormones, which is caused by the smoke inhaled from cigarettes. Research shows that there is a direct correlation between the amount of VFA and the number of cigarettes smoked daily in combination with an overall length of this dependence. If a smoker gets rid of his bad habit, the amount of VFA gradually reduces proportionately to the period without cigarettes (Coufalová, 2013).

An interesting fact is that smokers are usually characterized by lower BMI. Nicotine dramatically increases energy expenditure and may reduce appetite, which could explain the lower body weight in smokers and the reason why smoking cessation is followed by weight gain. However, according to various international studies, smokers have a higher percentage of VFA (Chiolero et al., 2008).

A study conducted in South Korea tried to evaluate the association between smoking and the type of obesity. The participants $(n=283)$ were divided into current smokers, former smokers and non-smokers. All participants underwent a measurement of BMI, waist circumference, total body fat, and the area of visceral ánd abdominal subcutaneous fat. Although smokers usually don't have higher BMI than nonsmokers, in this study they had more VFA, which is associated with an increased risk of metabolic disorders (Kim et al., 2012).

In another Korean study (Lee, 2012) they have proven that smokers have more visceral adipose tissue and that there is continual proportion between the amount of visceral adipose tissue and the number of cigarettes smoked per day and the length of smoking period.

In Japanese study (Komyia et al., 2006) that examined 450 heavily smoking men, almost two thirds of probands had a higher level of VFA. However, the results of this study suggest that smoking may not 
be the main and only factor affecting the accumulation of VFA in the body. The link between smoking and accumulation of VFA could partly be explained by low physical activity and unhealthy eating habits, especially among people with lower socioeconomic status. In another study, the authors confirmed results of other studies showing that smokers have a greater waist circumference and greater waist-tohip ratio (WHR), which is an indicator of VFA (Molenar et al., 2009). Simultaneously, these studies highlight the complexity of the link between smoking and other habits (exercise, diet, genetic predisposition and hormonal influences) contributing to the accumulation of abdominal and visceral fat.

One of the objectives of the project "Creating a research team led by a reintegrated Czech scientist for the purpose of determining the level of physical activity (inactivity) in selected age groups of men and women in the Czech Republic" (CZ. 1. 07/2. 3. 00/20. 0044) was also the testing of obesity in conjunction with the lifestyle of the Czech population.

Based on the results of foreign studies, we tried to determine the relationship between smoking on one hand, and VFA and degree of obesity in the abdomen on the other hand. WHR (waist-to-hip ratio) is often used to detect abdominal obesity, together with waist circumference. It is defined as the ratio between waist circumference (in centimeters) and hip circumference (in centimeters). In men, abdominal obesity is determined by values higher than 0.9 , while in women the value must be above 0.85 . We assumed that smokers would have a higher amount of VFA than non-smokers and the level of obesity in the abdominal area will reach higher values than in people, who do not smoke (www.medixa.org).

\section{METHODS}

The researched group included 1,412 people (658 men, 754 women). The probands filled a questionnaire and were divided into categories of smokers $(n=179)$ and non-smokers $(n=1233)$, and physically active $(n=1162)$ vs. physically inactive $(n=192)$. The amount of VFA was measured in standard laboratory conditions by the device InBody 720 equipped with the measurement technology DSM - BIA. Before running the test, subjects were acquianted with the basic guidelines in order to achieve the most accurate results.

The device InBody 720 measures non-invasively and quickly the amount $\left(\mathrm{cm}^{2}\right)$ of VFA in the body. If a person reaches $100 \mathrm{~cm}^{2}$ of VFA, this level still works as a protection of internal organs. When the amount of VFA exceeds the value of $100 \mathrm{~cm}^{2}$, the fat is moving inside, surrounds organs and begins to threaten human health. The verification of our hypotheses was performed by the following statistical methods: T-test (with the statistical significance level set at 0.05) and Fisher's LSD post - hoc test for tracing differences in the single-factor and multi-factor selection (ANOVA).

\section{RESULTS}

The results show that smokers achieve a higher average level of VFA compared to people who do not smoke (see Table 1, Figure 1), but the difference is not statistically significant $(p=0.31)$. In contrast, the difference in WHR and \% body fat reaches statistical signifance: Smokers have a greater WHR $(p=0.02)$ and higher $\%$ body fat $(p=0.04)$ than non-smokers. Therefore, smokers tend to have more fat in the abdominal area and more fat in general. 
Table 1. Smokers achieve a higher average level of VFA compared to people who do not smoke

\begin{tabular}{llllllll}
\hline \multirow{2}{*}{ Smoking } & $\mathrm{n}$ & \multicolumn{2}{c}{ Visceral fat $\left(\mathrm{cm}^{2}\right)$} & WHR & \multicolumn{3}{c}{ \%body fat } \\
\cline { 3 - 8 } & & average & $\mathrm{SD}$ & average & $\mathrm{SD}$ & average & $\mathrm{SD}$ \\
\hline Smokers & 179 & 93.37 & 6.15 & 0.890 & 0.005 & 25.49 & 0.70 \\
Non-smokers & 1233 & 86.63 & 2.34 & 0.878 & 0.002 & 23.95 & 0.27 \\
\hline
\end{tabular}

Smoking; Unweighted Means

Vertical bars denote 0,95 confidence intervals

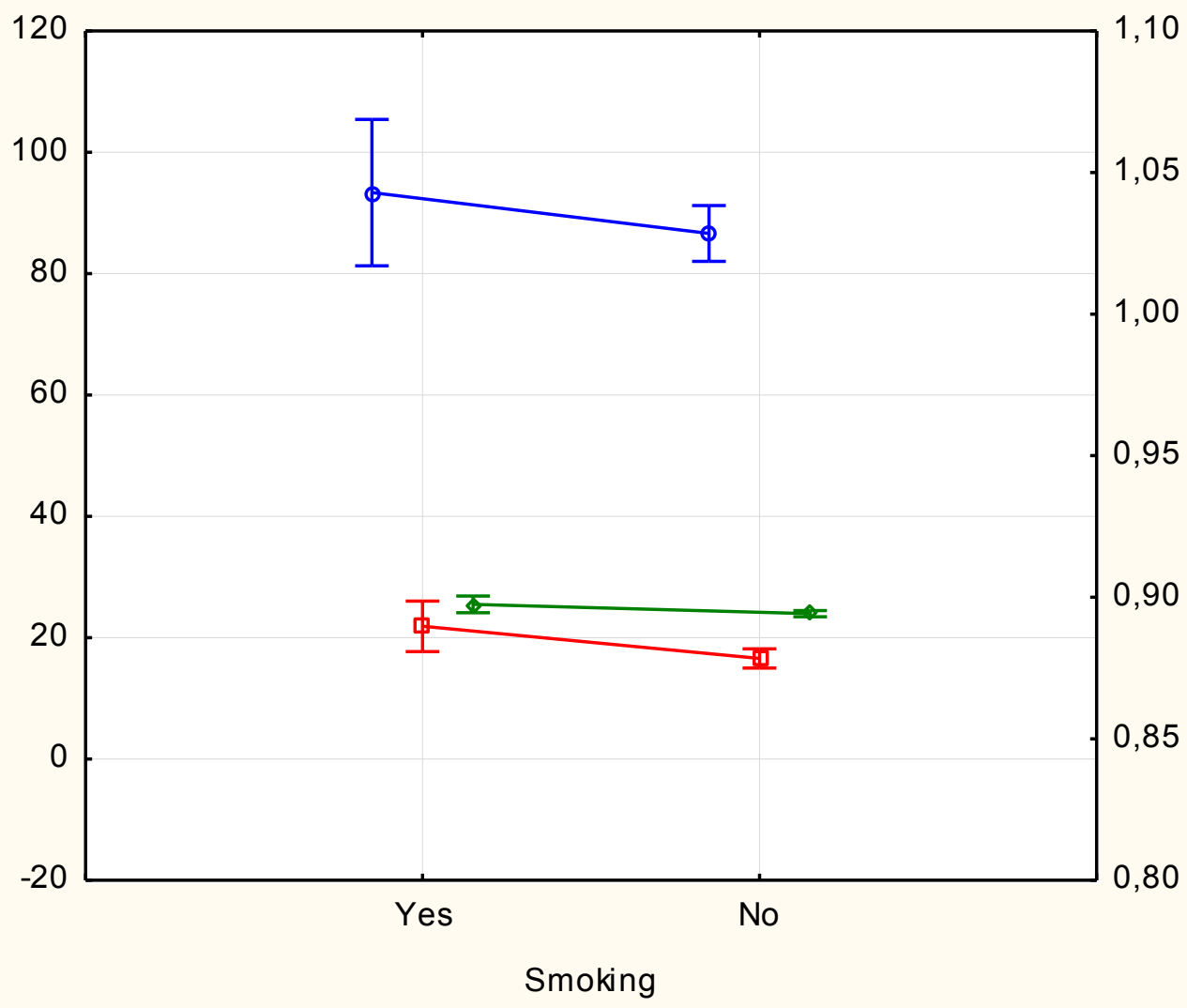

VFA (cm2)(L) WHR(R) $\%$ fat $(\mathrm{L})$

Figure 1. Smokers achieve a higher average level of VFA compared to people who do not smoke

When the tested subjects are compared according to the level of physical activity, the differences are even greater (Table 2, Figure 2). Physically active people have less VFA, a smaller WHR and less body fat than physically inactive people ( $\leq \leq 0.00001)$.

Table 2. Comparison according to the level of physical activity

\begin{tabular}{llllllll}
\hline Physical & $\mathrm{n}$ & \multicolumn{2}{l}{ Visceral fat $\left(\mathrm{cm}^{2}\right)$} & WHR & \multicolumn{3}{l}{ \%body fat } \\
\cline { 3 - 8 } activity & & average & SD & average & SD & average & SD \\
\hline Inactive & 192 & 114.48 & 6.00 & 0.907 & 0.004 & 30.52 & 0.65 \\
Active & 1162 & 83.49 & 2.44 & 0.876 & 0.002 & 23.26 & 0.26 \\
\hline
\end{tabular}


Physical activity; Unweighted Means

Vertical bars denote 0,95 confidence intervals

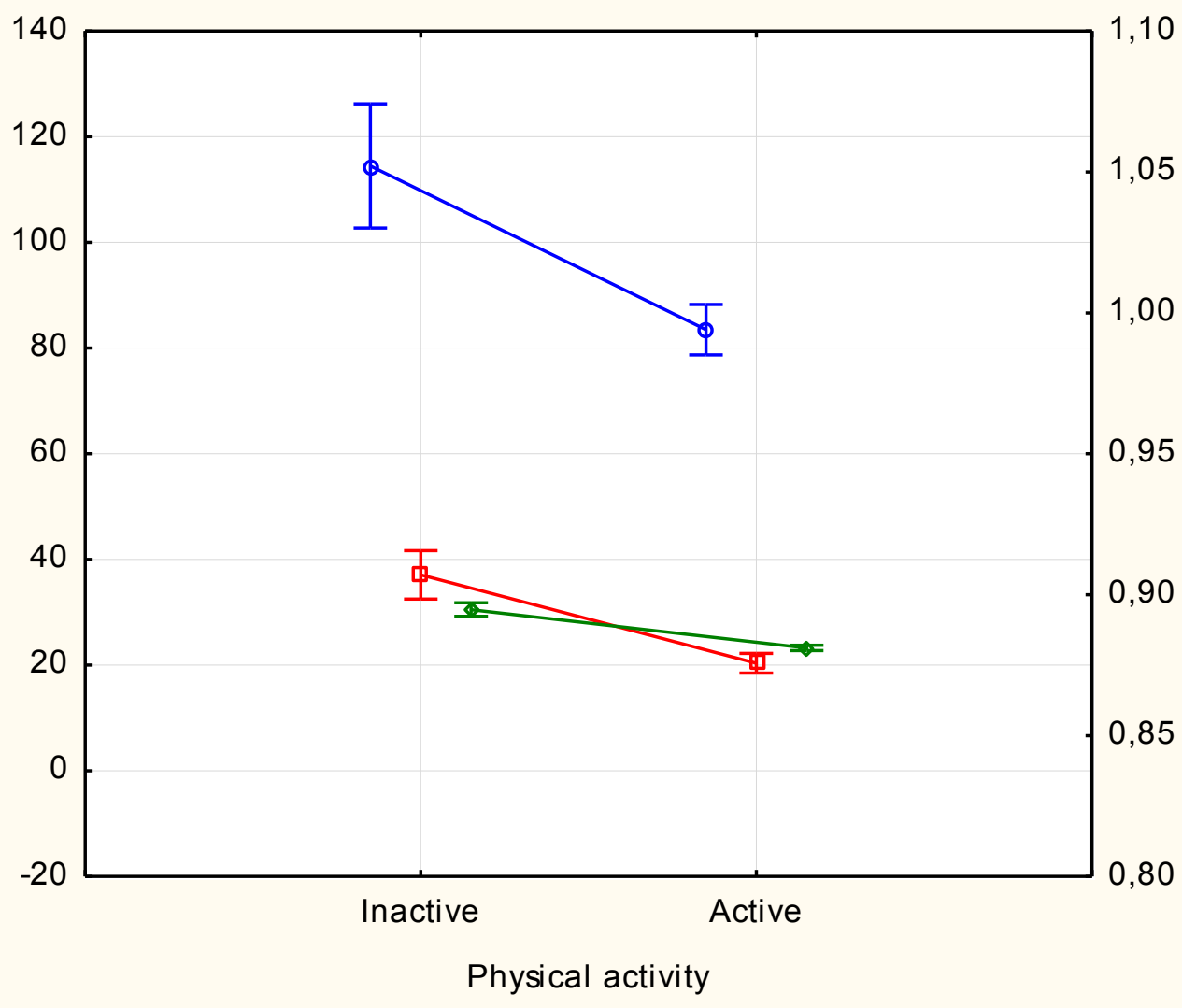

VFA (cm2)(L) WHR(R) $\%$ fat $(\mathrm{L})$

Figure 2. Comparison according to the level of physical activity

The comparison of our samples divided by smoking and physical activity demonstrated that physically active non-smokers had the least amount of VFA, the smallest WHR and the smallest \% body fat (Table 3, Figure 3). However, statistically significant differences in VFA were found only within categories divided by smoking $(p<0.05)$. Even physically active smokers had better results than physically inactive smokers. The largest statistically significant differences among categories were found in $\%$ fat. Quite unexpectedly, the worst results overall were found in physically inactive nonsmokers. In other words, the differences in smokers were smaller than in non-smokers.

Table 3. Comparison of our samples divided by smoking and physical activity

\begin{tabular}{|c|c|c|c|c|c|c|c|c|}
\hline \multirow{2}{*}{$\begin{array}{l}\text { Physical } \\
\text { activity }\end{array}$} & \multirow[t]{2}{*}{ Smoking } & \multirow[t]{2}{*}{$\mathrm{n}$} & \multicolumn{2}{|c|}{ Visceral fat $\left(\mathrm{cm}^{2}\right)$} & \multicolumn{2}{|l|}{ WHR } & \multicolumn{2}{|c|}{ \%body fat } \\
\hline & & & average & SD & average & average & SD & average \\
\hline Inactive & Smokers & 41 & 106.65 & 12.98 & 0.906 & 0.009 & 29.52 & 1.41 \\
\hline Active & Smokers & 131 & 88.97 & 7.26 & 0.884 & 0.005 & 24.38 & 0.79 \\
\hline Inactive & Non-smokers & 151 & 116.61 & 6.76 & 0.907 & 0.005 & 30.79 & 0.73 \\
\hline Active & Non-smokers & $\begin{array}{l}103 \\
1\end{array}$ & 82.72 & 2.59 & 0.875 & 0.002 & 23.09 & 0.28 \\
\hline
\end{tabular}


Smoking*Physical activity; Unweighted Means

Vertical bars denote 0,95 confidence intervals

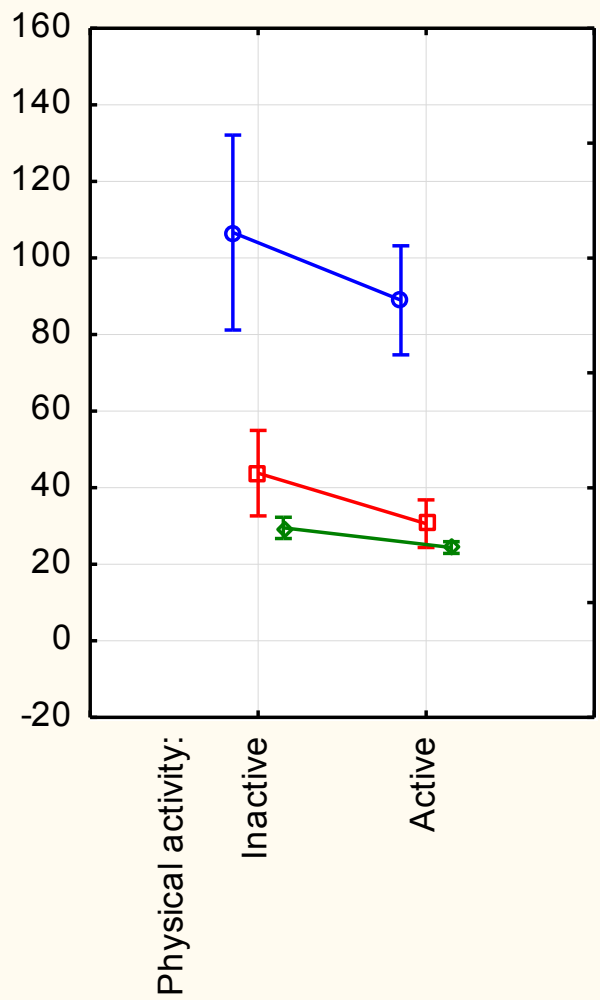

Smoking: Yes

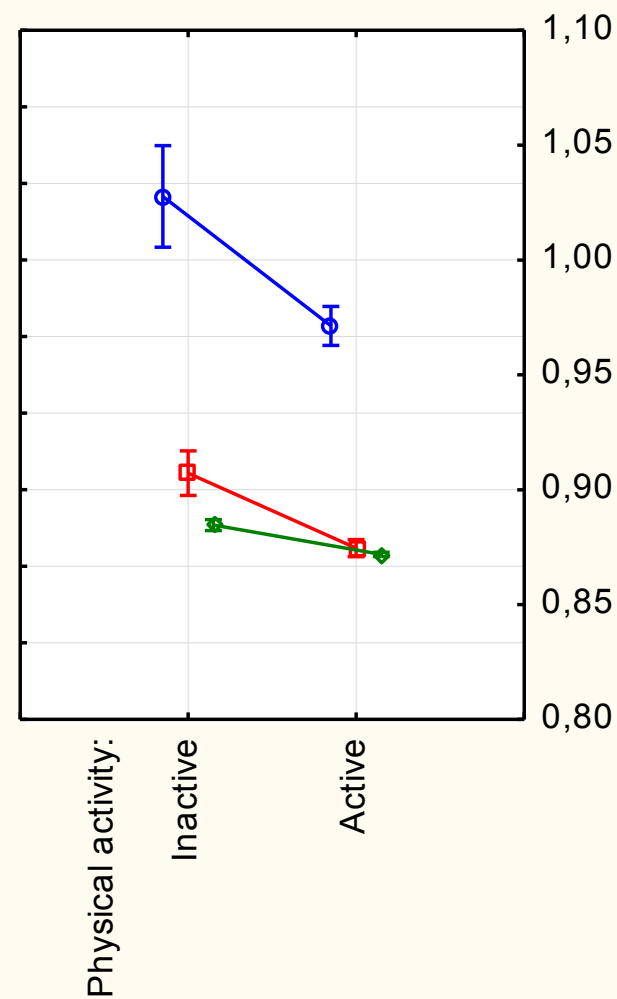

Smoking: No

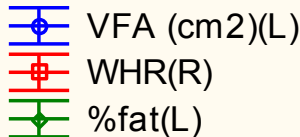

Figure 3. Comparison of our samples divided by smoking and physical activity

A subsequent analysis by gender and smoking showed that there exist sex-related differences with regard to fat deposition, which don't concern only well-known differences in \% fat (Table 4, Figure 4). Men have more VFA and a greater WHR than women, although only female non-smokers differ significantly from men in this regard $(p<0.05)$. As for $\%$ body fat, the differences between genders are highly significant across all categories divided by smoking $(\mathrm{p}=0.00008)$. Smokers in both genders tended to have more VFA, higher WHR and more body fat, but the results were not statistically significant. Nevertheless, the difference in VFA between smokers and non-smokers in women is noteworthy.

Table 4. Analysis by gender and smoking

\begin{tabular}{lllllllll}
\hline \multirow{2}{*}{ Gender } & \multirow{2}{*}{ Smoking } & $\mathrm{n}$ & \multicolumn{2}{c}{ Visceral fat $\left(\mathrm{cm}^{2}\right)$} & WHR & \multicolumn{2}{c}{ \%body fat } \\
\cline { 4 - 9 } Men & Smokers & 83 & 103.29 & 8.93 & 0.902 & 0.006 & 19.56 & 0.87 \\
\multirow{2}{*}{$\begin{array}{l}\text { Momen } \\
\text { Men }\end{array}$} & $\begin{array}{l}\text { Smokers } \\
\text { Nom- }\end{array}$ & 96 & 84.79 & 8.31 & 0.879 & 0.006 & 30.62 & 0.81 \\
& $\begin{array}{l}\text { Smokers } \\
\text { Somen }\end{array}$ & 575 & 100.44 & 3.39 & 0.895 & 0.002 & 18.69 & 0.33 \\
& $\begin{array}{l}\text { Non- } \\
\text { smokers }\end{array}$ & 657 & 74.54 & 3.18 & 0.864 & 0.002 & 28.55 & 0.31 \\
\hline
\end{tabular}

When the investigated samples were divided according to gender, smoking and physical activity (Table $5 a$ and $5 b$ ), the results further confirmed findings from Table 3: Physically inactive smokers of both 
genders had less visceral fat, smaller WHR and less body fat than physically inactive non-smokers. However, the differences were not statistically significant and the number of smokers in each category was too small for any meaningful conclusion. Therefore, perhaps the most interesting observation was the accentuation of the differences in VFA according to the level of physical activity, especially in nonsmoking men $(p=0.04)$ and women $(p=0.002)$. The range of WHR ratios and $\%$ body fat increased as well: Non-smoking, active women had the smallest WHR out of all predefined groups (0.859), while inactive, non-smoking men had the highest (0.927). Physically active, non-smoking men had the least $\%$ of body fat (18.0\%) and inactive, non-smoking women the highest (34.2\%). Differences between genders were always statistically significant only in terms of \% body fat: Men in all categories had less fat than women.
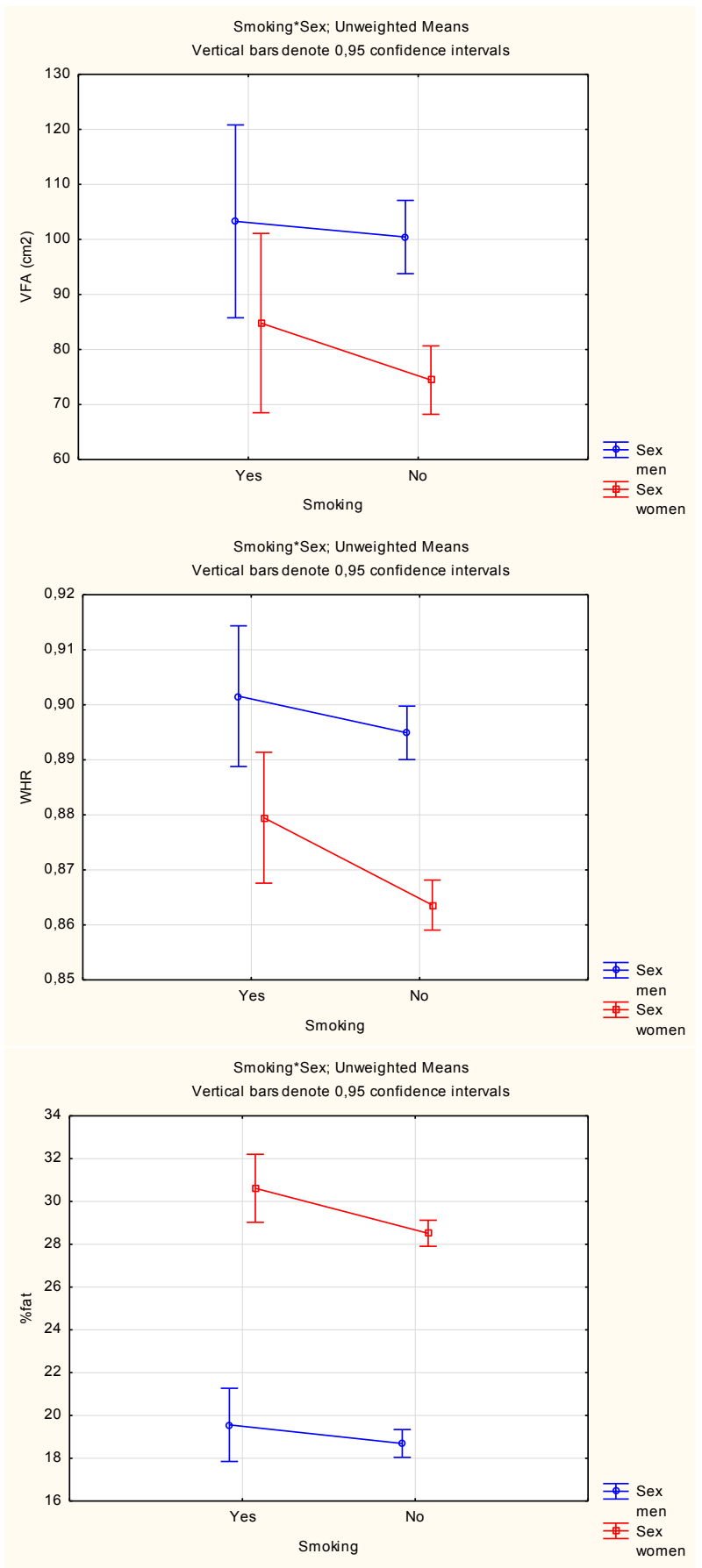

Figure 4. Analysis by gender and smoking 
Table 5a. Physical activity: Inactive

\begin{tabular}{lllllllll}
\hline \multirow{2}{*}{ Sex } & \multirow{2}{*}{ Smoking } & $\mathrm{n}$ & \multicolumn{2}{l}{ Visceral fat $\left(\mathrm{cm}^{2}\right)$} & WHR & \multicolumn{3}{c}{ \%body fat } \\
& & & average & SD & average & SD & average & SD \\
\hline Men & Smokers & 15 & 115.06 & 21.2 & 0.919 & 0.015 & 22.64 & 1.93 \\
Men & Non-smokers & 58 & 133.09 & 10.78 & 0.927 & 0.008 & 25.36 & 1.00 \\
Women & Smokers & 26 & 101.80 & 16.10 & 0.899 & 0.011 & 33.49 & 1.49 \\
Women & Non-smokers & 93 & 106.33 & 8.51 & 0.895 & 0.006 & 34.17 & 0.79 \\
\hline
\end{tabular}

Table 5b. Physical activity: Active

\begin{tabular}{lllllllll}
\hline \multirow{2}{*}{ Sex } & \multirow{2}{*}{ Smoking } & $\mathrm{n}$ & \multicolumn{2}{c}{ Visceral fat $\left(\mathrm{cm}^{2}\right)$} & WHR & \multicolumn{3}{c}{ \%body fat } \\
& & & average & SD & average & average & SD & average \\
\hline Men & Smokers & 63 & 100.43 & 10.34 & 0.898 & 0.007 & 18.97 & 0.96 \\
Men & Non-smokers & 485 & 97.70 & 3.73 & 0.892 & 0.003 & 18.00 & 0.35 \\
Women & Smokers & 68 & 78.35 & 9.96 & 0.872 & 0.007 & 29.40 & 0.92 \\
Women & Non-smokers & 546 & 69.53 & 3.52 & 0.859 & 0.003 & 27.67 & 0.33 \\
\hline
\end{tabular}

\section{DISCUSSION}

However, a more detailed analysis shows that this relationship may apply only for physically active individuals. In inactive individuals, it's smokers, who tend to have less visceral fat and body fat in general. With regard to the very limited size of the samples in smokers, we can't exclude the possibility that these paradoxical results are entirely accidental. Still, the fact that the trends are replicated in both genders suggests that they shouldn't be completely dismissed.

Although our results can not be interpreted unambiguously due to the small number of smokers and the effect of other factors such as unbalanced intake and energy expenditure, improper eating habits, genetic predispositions and hormonal influences, they show that the deposition of fat is much more influenced by the level of physical activity than by smoking. The illumination of the mutual relationship between smoking, physical activity and the deposition of fat would require larger samples.

\section{CONCLUSION}

Obesity is an epidemic of the 21 st century. In the Czech Republic, about $20 \%$ men and $30 \%$ women suffer from obesity and roughly $70 \%$ of the whole population is overweight. The reason lies in the imbalance between energy expenditure and intake. One of the main reasons, why people don't want to quit smoking, is a concern that they would gain weight (Veselý, 2013). Our results show that the level of visceral fat is very positively influenced by the level of physical activity and that non-smokers generally have less fat than smokers, which would make the above mentioned concerns unsubstantiated. To the contrary, smoking may be one of the main factors that influence the formation of visceral fat via an increase in plasma cortisol. Blood levels of cortisol are higher in smokers than in non-smokers. 


\section{REFERENCES}

1. Coufalová, J. (2013). Vliv cigaretového kouře na tělesnou hmotnost a príijem stravy. Nutriweb. Retrieved November 18, 2013 from http://nutriweb.cz/cs/clanky/onemocneni/vliv-cigaretovehokoure-na-telesnou-hmotnost-prijem-stravy

2. Chiolero, A., Faeh, D., Paccaud, F. \& Cornuz J. (2008). Consequences of smoking for body weight, body fat distribution, and insulin resistance. Am J Clin Nutr, 87(4), pp.801-809.

3. Komyia, H., Mori, Y., Yokos, T. \& Tajima, N. (2016). Smoking as a Risk Factor for Visceral Fat Accumulation in Japanese Men. Tohoku J Exp Med, 208, pp.123-132.

4. InBody - profesionální diagnostika složení těla. (n.d.), Retrieved November 21, 2013 from http://www.inbody.cz/

5. Kim, J.H., Shim, K.W., Yoon, Y.S., Lee, S.Y., Kin, S.S. \& Oh, S.W. (2012). Cigarette smoking increases abdominal and visceral obesity but not overall fatness: an observational study. PLoS One, $7:$ e45815.

6. Lee, K., Lee, C.M., Kwon, H.T., Oh, S.W., Choi, H., PARK, J.H., \& Cho, B. (2012), Associations of smoking and smoking cessation with CT-measured visceral obesity in 4656 Korean men. Preventive Medicine, 55(3), pp.183-187.

7. Matoulek, M., Svačina Š. \& Lajka, J. (2010), Výskyt obezity a jejích komplikací v České republice. Vnitřní Lékařství, 56(10), pp.1019-1027.

8. Molenar, E.A., Massaro, J.M., Jacques, P.F., Pou, K.M., Ellison, R.C., Hoffmann, U., Pencina, K., Shadwick, S.D., Vasan, R.S., O'Donnell, C.J. \& Fox, C.S. (2009), Association of lifestyle factors with abdominal subcutaneous and visceral adiposity. The Framingham Heart Study, 32(3), pp.505-510. Obezita. (n.d.) Retrieved October 10, 2013 from http://cs.medixa.org/

9. Sucharda, P. (2010). Kouření a obezita. Vnitřni Lékařství, 56(10), pp.1053-1057.

10. Veselý, O. (2013). Základy nárys etiopatogeneze metabolického syndromu. Tvorba a ověření e-learningového prostředí pro integraci výuky preklinických a klinických předmětů na LF a FZV UP OLOMOUC. CZ. 1. 07/2.2.00/15.0313. Retrieved November 20, 2013 from http://pfyziollfup.upol.cz/castwiki2/?p=9118 